Darimus, FUNGSI LEMB AGA-LEMBAGA DAL AM PEI AKS ANAAN..

\section{FUNGSI LEMBAGA-LEMBAGA DALAM PELAKSANAAN \\ OTONOMI DI BIDANG PENDIDIKAN: TELAAH ATAS KELEMBAGAAN DAN SDM}

\author{
Darimus \\ Kantor Wilayah Departemen Agama Propinsi Riau
}

\section{Abstract}

The Function of Institutions in the Implementation of Autonomy in Education: A Study on Institutions and Human Resources : The implementation of good quality and equitable education is facing more complex challenges. Educational institutions which do not function properly and the low quality of human resources are the main factors besides other factors that need immediate attention in the world of Islamic education. The efficiency in education does require more decentralized management, as a matter of fact. The function of institutions in the implementation of autonomy in the area of Islamic education in particular should be able to manage and apply educational techniques autonomously either in the field of School-Based Management, organization, personnel, curriculum, facilities and infrastructure, studentship, cost and public relations as an opportunity or external environment as a challenge. The reposition of Islamic education in madrasah, modernization of boarding houses, and autonomy in bigher education are the expectations of all sides in order to achieve good quality education which is managed by professional technical practitioners.

Keywords: Educational institutions, Autonomy in education, Madrasah.

\section{Pendahuluan}

Kebijakan otonomi daerah berdasarkan Undang-Undang Nomor 22 Tahun 1999 telah memberi kesempatan kepada daerah utuk mengatur dan mengurus kepentingan masyarakatnya menurut prakarsa sendiri berdasarkan aspirasi masyarakat sesuai dengan peraturan perundang-undangan. Dengan demikian pemerintah daerah memiliki kesempatan yang besar untuk menetapkan secara efisien dan efektif
Al-Fikra: Jurnal Ilmiah Keislaman, Vol. 5, No. 2, Juli-Desember 2006

dalam hal perencanaan, pelaksanaan dan evaluasi terhadap kegiatan pemerintahan dan pembangunan daerah. ${ }^{1}$

Dengan kebijakan otonomi daerah berarti pemerintah menempatkan fungsi-fungsi penyelenggaraan pemerintahan, pembangunan dan pelayanan publik lebih dekat kepada jangkauan masyarakat, yang dilaksanakan oleh pemerintah daerah. Penyelenggaraan otonomi daerah harus memegang prinsip-prinsip demokrasi, partisipasi masyarakat, pemerataan dan keadilan serta memperhatikan potensi dan keanekaragaman daerah. Prinsip-prinsip ini sejalan dengan karakteristik Good Govermance yang meliputi; demokrasi, akuntabilitas, keterbukaan, transparansi, penataan hukum, penghormatan HAM, partisipasi masyarakat dan sebagainya. ${ }^{2}$

Masalah pendidikan merupakan kepentingan yang mendapatkan prioritas utama sejak awal kehidupan manusia. Bahkan Rasulullah sendiri telah mengisyaratkan bahwa proses belajar bagi setiap insan adalah sejak ia masih dalam kandungan ibunya sampai keliang kubur, dan sejak dari rumah tangga orang tuanya sampai jauh ke negara lain. Ada beberapa prinsip-prinsip dasar pendidikan Islam yang harus diperhatikan, yaitu sebagai berikut : ${ }^{3}$ (1) azas integrasi; (2) azas keseimbangan; (3) azas persamaan; (4) pendidikan seumur hidup; dan (5) azas keutamaan.

Sebagai agama yang mengutamakan pendidikan, maka sepanjang kurun waktu kehidupan Islam hingga kini telah muncul banyak para ahli menyumbangkan buah pikirannya khususnya dalam bidang pendidikan, seperti; Imam al-Garzaly, Ibnu Kbladun, Ibnu Sina, AtThabthawi, Muhammad Abduh, Al-Qabisi, dan lain-lain, yang telah menyumbangkan buah pikirannya untuk kesempurnaan dan kemajuan bidang pendidikan Islam yang berlandaskan pada al-Qur'an dan Sunnah Nabi. ${ }^{4}$

${ }^{1}$ Lembaga Administrasi Negara, Sistem Manajemen Kinerja Otonomi Daerah, (Jakarta: Pusat Kajian Kinerja Otonomi Daerah, LAN, 2004), hlm. 15

2 Ibid., hlm. 15

3 Munzir Hitami, Mengonsep Kembali Pendidikan Islam, (Pekanbaru: Infinite Press, 2004), hlm.24-31

${ }^{4}$ M. Arifin, Perbandingan Pendidikan Islam, (Jakarta: PT. Rineka Cipta, 2002), hlm.v 
Darimus, FUNGSI LEMBAGA-LEMBAGA DAL AM PEL AKS ANAAN...

Fungsi lembaga pendidikan Islam sangat mempunyai peranan penting dalam dunia Islam untuk membentuk akhlak dan mental umat Islam. Pertama Masjid sebagai lembaga pendidikan Islam pertama, merupakan tempat menghimpun kekuatan umat Islam baik dari segi fisik maupun mental. Di samping tempat shalat, masjid juga berfungsi sebagai madrasah, universitas, majelis nasional, dan pusat-pusat pemberian fatwa, serta tempat pengembangan para pejuang dan patriot-patriot bangsa dari zaman ke zaman.

Kedua Al-Kuttab yang merupakan lembaga pendidikan pada permulaan sejarah Islam, ketika Nabi memerintahkan para tawanan perang (Badar) yang dapat menulis dan membaca untuk mengajar 10 anak-anak Madinah (bagi setiap tawanan). Al-Kuttab berkembang sangat pesat sejak abad ke $2 \mathrm{H}$, dan yang terkenal adalah Kuttab Abi Qasim Al-Balchi.

Ketiga, Madrasah. Madrasah yang pertama adalah Madrasah Baehaqiyyah dikota Naisabur karena Masjid penuh oleh halaqah-halaqah (pengajian-pengajian) pada abad ke $4 \mathrm{H}$. Madrasah yang termashur adalah Nizamiyah di Bagdad dan Nizamiyah di Nassab abad ke $5 \mathrm{H}$, yang diririkan oleh Nizam Mulk, seorang menteri Sultan dari Malik AlSyeljugi (465 s/d 485 H) dimana Imam Al-Ghazali mengajar di Madrasah ini.

Keempat, Zawiyah. Zawiyah yang pertama adalah sudut masjid digunakan tempat I'tikaf dan mensyi'arkan urusan agama, kemudian berkembang menjadi temapt tinggal tetap dan cocok untuk pendidikan agama Islam. Ketika pemerintahan Islam di Andalusia mundur karena musuh, Zawiyah berkembang menjadi tempat mengembleng para tentara untuk melawan kaum Nasrani.

Kelima, Al-Maristan sebagai lembaga ilmiah yang paling penting dan sebagai tempat penyembuhan dan pengobatan pada zaman keemasan Islam. Di dalamnya para dokter mengajar ilmu kedokteran. Dokter yang terkenal adalah Moh. Bin Zakaria Ar-Razi, beliau pernah memimpin Maristan di Bagdad pada masa khalifah I Muktafa tahun $311 \mathrm{H}$.

Setelah kita mengetahui sejarah lembaga pendidikan di dunia Islam pada umumnya, betapa pentingnya suatu lembaga pendidikan agar proses belajar itu berjalan dengan baik dan dapat mencapai tujuan
A1-Fikra: Jurnal Ilmiah Keislaman, Vol. 5, No. 2, Juli-Desember 2006 seperti yang diharapkan, maka proses belajar tersebut tidak terlepas dari fugsi suatu lembaga sebagai tempat dan media untuk pelaksanaan proses belajar mengajar tersebut.

Dalam UU Nomor 25 Tahun 2000 tentang Program Pembangunan Nasional (PROPENAS), dinyatakan bahwa ada 3 tantangan besar dalam bidang Pendidikan di Indonesia, yaitu (1) mempertahankan hasil-hasil pembangunan pendidikan yang dicapai; (2) mempersiapkan sumber daya manusia yang kompeten dan mampu bersaing dalam pasar kerja global; dan (3) sejalan dengan diberlakukannya otonomi daerah system pendidikan nasional dituntut untuk melakukan perubahan dan penyesuaian sehingga dapat mewujudkan proses pendidikan yang lebih demokratis, memperhatikan keberagaman, memperhatikan kebutuhan daerah dan peserta didik, serta mendorong peningkatan partisipasi masyarakat. ${ }^{5}$

Dalam konteks pelaksanaan otonomi daerah ditegaskan bahwa system pendidikan nasional yang bersifat sentralistis selama ini kurang mendorong terjadinya demokratisasi dan desentralisasi penyelenggaraan pendidikan. Sebab sistem pendidikan yang sentralistis diakui kurang bisa mengakomodasi keberagaman daerah, sekolah, serta peserta didik, bahkan cenderung mematikan partisipsi masyarakat dalam pengembangan pendidikan.

Menguatnya aspirasi bagi otonomisasi dan desentralisasi pendidikan tidak terlepas dari kenyataan adanya kelemahan konseptual dan penyelenggaraan pendidikan nasional, yaitu (1) kebijakan pendidikan nasional sangat sentralistik dan serba seragam, yang pada gilirannya mengabaikan keragaman sesuai dengan realitas kondisi, ekonomi, budaya masyarakat Indonesia di berbagai daerah; (2) kebijakan dan penyelenggaraan pendidikan nasional lebih berorientasi pada pencapaian target-target tertentu, seperti target kurikulum, yang akhirnya mengabaikan proses pembelajaran yang efektif dan mampu menjangkau seluruh ranah dan potensi anak didik.

Dengan kehadiran UU Nomor 32 Tahun 2004 (dimulai dengan UU Nomor 29 Tahun 1999) tentang Pemerintahan Daerah, dimana

${ }^{5}$ Hasbullah, Otonomi Pendidikan, Kebijakan Otonomi Daerah dan Implikasinya terhadap Penyelenggaraan Pendidikan, (Jakarta: PT.RajaGrafindo Persada, 2006), hlm. 1 
Darimus, FUNGSI LEMBAGA-LEMBAGA DALAM PELAKS ANAAN...

sejumlah kewenangan telah diserahkan, memungkinkan daerah untuk melakukan kreasi, inovasi, dan improvisasi dalam upaya pembangunan daerahnya, termasuk dalam bidang pendidikan. Pemberlakuan otonomi daerah tersebut membawa implikasi terhadap perubahan dalam penyelenggaraan pendidikan, salah satunya adalah berkurangnya peran pemerintah pusat dalam pengelolaan pendidikan.

Menurut analisis beberapa pakar dan praktisi pendidikan, di Indonesia saat ini paling tidak ada lima persoalan pokok yang harus dipikirkan secara kontekstual di daerah bersangkutan, yakni; (1) mutu pendidikan, (2) efisiensi pengelolaan, (3) pemerataan, (4) peran serta masyarakat, (5) dan akuntabilitas pendidikan. Otonomi dalam konteks ini tidak ditafsirkan sebagai pengentalan warna kedaerahan yang primordialistis, tetapi dipahami dari sisi positif yang mengembangkan semua potensi yang dimiliki. ${ }^{6}$

Meskipun desentralisasi pendidikan merupakan sebuah keharusan, namun dalam realitasnya, pelaksanaan desentralisasi pendidikan terkesan satu tindakan yang agak tergesa-gesa dan tidak siap. Hal ini bisa dilihat dari belum memadainya sumber daya manusia (SDM) daerah, minimnya sarana dan prasarana, manajemen pendidikan yang belum optimal, disamping juga sekian banyak permasalahan yang masih dihadapi dunia pendidikan di daerah.

Untuk itulah penulis coba mendiskripsikan dalam suatu makalah yang berjudul : Fungsi Lembaga-lembaga dalam Pelaksanaan Otonomi di Bidang Pendidikan; Telaah atas Kelembagaan dan SDM.

\section{Modernisasi Pendidikan Pesantren}

Kehidupan di pesantren menampakan semangat demokrasi karena mereka praktis bekerjasama mengatasi problema non-kurikuler mereka, sistem pondok pesantren mengutamakan kesederhanaan, idealisme, persaudaraan, persamaan, rasa percaya diri dan keberanian hidup. Alumni pondok pesantren tidak ingin menduduki jabatan pemerintahan, sehingga mereka hampir tidak dapat dikuasai oleh

${ }^{6}$ Ibid, hlm. 3
Al-Fikra: Jurnal Ilmiah Keislaman, Vol. 5, No. 2, Juli-Desember 2006

pemerintah. ${ }^{7} \mathrm{Ki}$ Hajar Dewantara yang dikenal sebagai tokoh pendidikan nasional menyatakan bahwa Pondok pesantren merupakan dasar pendidikan nasional, karena sesuai dan selaras dengan jiwa dan kepribadian bangsa Indonesia. ${ }^{8}$

Meskipun demikian, pesantren juga tidak luput dari berbagai kritik terhadap kelemahan pesantren, hal ini terutama terjadi di saatsaat menjelang kemerdekaan, dimana kondisi pondok pesantren telah mencapai titik kritis sebagai lembaga pendidikan tradisional yang tertutup dan statis. Islam yang diajarkan oleh pondok pesantren pada umumnya adalah Islam yang mengalami teror dan intimidasi musuh Islam, yakni Islam yang ritualistic dan sufistik bahkan mengarah kepada feodalistik. ${ }^{9}$

Dilihat dari fungsi dan pemanfaatan pesantren sebagai lembaga pendidikan Islam yang memiliki ciri khas, maka di daerah lain (luar Jawa) hidup lembaga pendidikan Islam yang mempunyai fungsi dan kemanfaatan yang sama dengan nama yang berbeda, misalnya meunasab di Aceh, Surau di Sumatera, rangkang di Kalimantan. Bahkan menurut para ahli lain dikenal dengan sebutan zawiyah di mana letak bangunannya terpencil dari pusat keramaian dan system belajarnya melingkar yang dikenal dengan system bandongan. ${ }^{10}$ Dan tegak berdirinya pesantren sekurang-kurangnya harus didukung oleh lima unsur yaitu; kyai, masjid, santri, pondok, dan pengajaran kitab-kitab Islam klasik. ${ }^{11}$

Dalam upaya pengembangan pondok pesantren dalam konteks otonomi daerah, paling tidak ada dua hal yang memerlukan perhatian secara khusus, yaitu :

7 Amien Rais, Cakrawala Islam, antara cita dan fakta, (Bandung: Mizan, 1989), hlm. 162.

8 Alamsyah Ratu Prawiranegara, Pembinaan Pendidikan Agama, (Jakarta: Depag RI, 1982), hlm. 41

${ }^{9}$ Fuad Amsyari, Masa Depan Umat Islam Indonesia, (Bandung: Al-Bayan, 1993), hlm. 111

${ }^{10}$ Departemen Agama RI, Rekonstruksi Sejarah Pendidikan Islam di Indonesia, (Jakarta: Direktorat Jenderal Kelembagaan Agama Islam, 2005), hlm. 95-96.

11 Zamakhsari Dhofier, Tradisi Pesantren, Studi Pandangan Hidup Kyai, Jakarta: LP3ES, 1986), hlm. 44 
Darimus, FUNGSI LEMBAGA-LEMBAGA DALAM PELAKS ANAAN...

1. Pengembangan yang bersifat eksternal, di antaranya sebagai berikut:

a. Tetap menjaga agar citra pondok di mata masyarakat sesuai dengan harapan masyarakat, harapan orang tua yang memasukan anaknya ke pondok. Untuk hal ini, mutu lulusannya harus mempunyai nilai tambah dari lulusan pendidikan lainnya yang sederajat.

b. Meskipun diakui kekhususannya, pesantren merupakan bagian dari pendidikan nasional, dan santrinya pun merupakan bagian integral dari masyarakat karena mereka dipersiapkan untuk memikul tanggung jawab dalam maysrakat. Oleh sebab itu, pesantren harus selalu peduli terhadap aturan main dan tata aturan dalam pendidikan nasional.

c. Santri-santri hendaknya dipersiapkan untuk mampu berkompetsisi dalam masyarakat yang majemuk.

d. Pesantren hendaknya terbuka terhadap setiap perkembangan dan perubahan yang terjadi, terhadap temuan-temuan ilmiah, termasuk temuan baru dalam dunia pendidikan, artinya pesantren tidak tenggelam pada dunianya sendiri.

e. Pesantren juga diharapkan dapat dijadikan sebagai pusat studi (laboratorium agama) yang dapat membahas berbagai perkembangan dalam masyarakat, guna kepentingan bangsa dan umat Islam khususnya.

2. Pengembangan yang bersifat internal, di antaranya sebagai berikut:

a. Kurikulum pesantren hendaknya dirancang sedemikian rupa untuk memenuhi kebutuhan santri, baik minat, bakat, atapun kemampuannya. Hal ini memungkinan karena penelusuran bakat dan minat dan minta mereka lebih mudah dilakukan dipesantren, sebab umumnya santri tinggal di pondok. Kurikulum ini sekaligus dapat menyatukan dengan baik antara aspek intelektual-emosional, agama-spiritual, dan kinerjapsikomotor.

b. Tenaga pengajar pesantren, tanpa mengurangi peran kiai, untuk pengembangan pesantren yang adaptif kiranya perlu kriteriakriteria khusus dalam perekrutan tenaga pengajarnya. Minimal hal-hal yang perlu dipertimbangkan; (1) mempunyai
Al-Fikra: Jurnal Ilmiah Keislaman, Vol. 5, No. 2, Juli-Desember 2006

pengetahuan keagamaan yang cukup mantap. Sering disebut ulama-ilmuwan-pendidik, (2) ia seorang profesional dalam bidang ilmu yang diajarkannya, punya kemampuan dalam mentransfer ilmunya kepada santri dengan baik dan tepat, serta bias mengkombinasikan ilmu agama dengan ilmu yang diajarkannya. Dan ini merupakan kombinasi ilmuwan-pendidik dan ulama.

c. Proses pembelajaran di pesantren, karena jumlah santri yang cukup banyak dan santri juga tidak lagi menerima informasi sepihak, perlu dikembangkan daya nalar, kritik, dan kreativitas santri.

d. Sarana pendidikan di pesantren, factor sarana sangat menentukan, hampir bias dipastikan dengan sarana belajar yang lengkap, hasil yang dicapai akan lebih baik ketimbang yang tidak memilki sarana. Sarana-sarana yang dimaksud adalah seperti ruang belajar yang baik, perpustakaan yang lengkap, peralatan laboratorium, media-media belajar, komputer, teknologi jaringan dan sebagainya.

e. Aktivitas kesantrian tidak hanya meliputi mengaji, shalat berjamaah, tadarus, memaca kitab dan sebagainya. Untuk kondisi sekarang wawasan santri perlu diperluas dengan aktivitas yang lebih banyak. Mereka perlu meneliti sesuatu yang ada di lingkungannya sehingga temuannya dapat membenarkan betapa besarnya kekuasaan Tuhan Yang Maha Esa, mereka perlu berolah raga dan seni, berorganisasi, belajar bisnis dan sebagainya. Aktivitas tersebut akan sangat membantu santri dalam pengembangan kualitas dan kesiapan berkompetsisi setelah keluar dari pesantren.

\section{Reposisi Pendidikan Madrasah}

Madrasah adalah salah satu jenis lembaga pendidikan Islam yang berkembang di Indonesia. Namun kehadiran Madrasah di Indonesia terjadi pada awal abad ke-20. Tampaknya tokoh Zainuddin Labay dapat disebut sebagai tokoh pertama yang pada tanggal 10 Oktober 1915 mendirikan lembaga pendidikan Islam (madrasah) di Padang 
Darimus, FUNGSI LEMBAGA-LEMBAGA DALAM PELAKS ANAAN...

Panjang, mungkin yang dimaksud juga memberikan pelajaran umum disamping pelajaran agama, sebelum berkembangnya lembaga serupa di berbagai daerah. ${ }^{12}$ Ada juga yang berpendapat bahwa Madrasah Muawanatul Muslimin Kenepan Kudus di Jawa Tengah yang d dirikan tanggal 7 Juli 1915.13

Dengan adanya undang-undang tentang system pendidikan nasional adalah merupakan seperangkat aturan atau ketentuan yang terpadu dari semua aturan dan kegiatan pendidikan yang berkaitan satu dengan yang lainnya untuk mengusahakan tercapainya tujuan pendidikan nasional. Bagi umat Islam, madrasah merupakan lembaga pendidikan Islam yang berakar dari tradisi Islam sendiri sehingga tidak mungkin ditangani secara sekuler. Tetapi pemerintah juga memahami bahwa umat Islam menuntut hak dan status yang lebih baik bagi madrasah sebagai bagian dari system pendidikan nasional sehingga kedudukan dan orientasinya sama dengan sekolah. ${ }^{14}$

Madrasah sebagai lembaga pendidikan Islam walaupun mempunyai tujuan khusus akan tetapi pendidikan yang dilaksanakannya harus merupakan bagian yang tidak terpisahkan dari system pendidikan nasional dalam arti bahwa pendidikan pada madrasah harus dapat memberikan konstribusi terhadap tujuan pendidikan nasional. Sistem pendidikan yang berlaku di Indonesia khususnya dari awal sampai proses menamatkan anak didik telah diatur oleh pusat sebagai pemegang kebijakan, maka perlu adanya upaya restrukurisasi ataupun reformasi dalam dunia pendidikan. Mungkin adanya kurikulum berbasis sekolah adalah merupakan langkah awal dalam menata ulang system pendidikan yang sudah berlaku untuk kemajuan suatu lembaga pendidikan yang akan datang.

Lembaga pendidikan Islam khususnya madrasah adalah sangat dibutuhkan oleh masyarakat bangsa Indonesia yang mayoritas

12 Taufik Abdullah, School and Politic: The Kaum Muda Movement in West Sumatera, (New York: Cornel University, 1971), hlm.34 Lihat juga Hamka, Kenangkenangan Hidup, (Jakarta: Gapura, 1951), hlm. 40 1979).

13 Mahmud Yunus, Sejarah Pendidikan Islam, (Jakarta: Hidakarya Agung,

14 Maksum, Madrasah, Sejarah dan Perkembangannya, (Jakarta: Logos Wacana Ilmu, 1999), hlm. 148
A1-Fikra: Jurnal Ilmiah Keislaman, Vol. 5, No. 2, Juli-Desember 2006

beragama Islam. Madrasah yang pada awalnya masih sangat sederhana bentuknya, dan kemudian terdapat pembaharuan demi peningkatan mutu pendidikannya terlebih sekarang ini memasuki era globalisasi yang ditandai dengan era reformasi. Era reformasi selain menghadirkan peluang positif untuk hidup mudah, nyaman, murah, indah, dan maju, juga dapat menghadirkan peluang negatif sekaligus menimbulkan keresahan, penderitaan dan penyesatan. Dalam kondisi seperti itu tugas madrasah sebagai lembaga pendidikan Islam adalah perlu menciptakan dan mengembangkan system pendidikan yang menghasilkan lulusan yang mampu memilih dan bersaing tanpa kehilangan jati dirinya.

Pengembangan madrasah yang dilakukan sejak diberlakukannya UU No.2 Tahun 1989 telah menunjukan banyak kemajuan. Beberapa indicator yang menunjukan keberhasilan pengembangan madrasah dilihat dari kondisi fisik madrasah (terutama negeri) seudah banyak yang cukup baik dan bagus. Bahkan ada beberapa madrasah yang dijadikan model dilengkapi dengan sarana pendidikan yang memadai seperti pusat belajar, laboratorium, perpustakaan. Guru-guru madrasah juga telah ditingkatkan kompetensi dan kemampuannya melalui berbagai pendidikan dan pelatihan baik di dalam maupun di luar negeri.

Sejak berlakunya UU No. 2 Tahun 1989 tersebut, pendidikan madrasah telah menjadi bagian dari system pendidikan nasional. Oleh karena itu, visi dan misi pendidikan madrasah tentunya sejalan dengan visi dan misi pendidikan nasional.

Ketika sekarang banyak pihak berbicara tentang strategi pendidikan dengan pendekatan yang dikelola oleh masyarakat (community based management), madrasah khususnya dan pendidikan Islam pada umumnya telah memiliki pengalaman dan sejarah yang panjang mengenai hal tersebut. Inilah kekuatan utama yang dimiliki oleh madrasah. Selanjutnya madrasah akan bermuara pada manajemen berbasis sekolah (school based management) yakni pengelolaan pendidikan yang dilakukan oleh madrasah secara otonom.

Kebijakan pengembangan madrasah yang dilakukan oleh Departemen Agama selama ini mengakomodasikan tiga kepentingan. Pertama, kebijakan itu memberikan ruang tumbuh yang wajar bagi 236 
Darimus, FUNGSI LEMBAGA-LEMBAGA DALAM PELAKS ANAAN... aspirasi utama umat Islam, yakni menjadikan madrasah sebagai wahana untuk membina ruh atau praktik hidup Islami. Kedua, kebijakan itu memperjelas dan memperkokoh keberadaan madrasah sebagai ajang membina warga negara yang cerdas, berpengetahuan, berkepribadian serta produktif dan sederajat dengan system sekolah. Ketiga, kebijakan itu harus bisa menjadikan madrasah mampu merespons tuntutan-tuntutan masa depan. ${ }^{15}$

Sementara itu, kebijakan operasional dalam upaya menghadapi era globalisasi, Departemen Agama RI telah menyiapkan pemberdayaan madrasah melalui sejumlah kebijakan seperti Madrasah Terbuka (khusus tingkat Tsanawiyah), Madrasah Reguler (sekolah umum bercirikan khusus Agama Islam), Madrasah Aliyah Keagamaan (MAK), Madrasah Aliyah Program Keterampilan, Madrasah Tsanawiyah dan Aliyah Model, serta Madrasah Kembar. Sebagai institusi social madrasah dituntut untuk melakukan inovasi-inovasi dan modifikasi system pendidikan dan kelembagaannya agar tidak ketinggalan dengan akselerasi modernisasi dan perubahan.

Oleh sebab itu, di era otonomi daerah dan otonomi pendidikan, reposisi kelembagaan Islam yang dalam hal ini diwakili madrasah, ditujukan pada berkembangnya identitas lembaga tersebut yang pada akhirnya akan melahirkan pribadi peserta didiknya yang mempunyai identitas karena pembinaan madrasah dengan ciri khas dimilikinya.

\section{Perguruan Tinggi Agama Islam}

Perguruan tinggi agama Islam sebagai salah satu lembaga pendidikan Islam sangat dibutuhkan oleh masyarakat bangsa Indonesia yang mayoritas beragama Islam. Perguruan tinggi agama Islam seperti UIN, IAIN, STAIN, PTAIS perlu pembaharuan demi peningkatan mutu pendidikannya untuk memasuki dunia kerja (pasar kerja) di era global. Karena tidak sedikit lembaga pendidikan yang

${ }^{15}$ Malik Fajar, 1999 yang dikutip oleh Hasbullah, Otonomi Pendidikan, (Jakarta: Rajgrafindo Persada, t.th), hlm. 164.
Al-Fikra: Jurnal Ilmiah Keislaman, Vol. 5, No. 2, Juli-Desember 2006

lulusannya tidak siap berkompetisi memasuki dunia kerja tidak dibutuhkan oleh pasar kerja. ${ }^{16}$

Tuntutan untuk menata ulang Sistem Pendidikan Nasonal, bersamaan dengan tuntutan menata ulang system dari model pemerintahan sentralis ke desentralis atau otonomi pemerintaha daerah (otoda), yaitu dengan lahirnya UU No. 22 tahun 1999 dengan pemerintahan daerah dan UU No. 25 tahun 1999 tentang perimbangan keuangan pusat dan daerah. Namun demikian pemerintah pusat maupun pemerintah daerah hanya berperan sebagai funding agency, pemicu dana, untuk selanjutnya sekolah sendiri yang mengembangkannya.

Perguruan tinggi mengemban misi yang mulia yang berkorelasi dengan buman educatif. Keberadaan perguruan tinggi diorientasikan menjadi pilar secara general untuk nation building. Dengan demikian lembaga pendidikan Islam harusnya membenahi dari aspek fungsi dan posisinya sebagai lembaga yang mempersiapkan generasi yang akan mengisi kehidupan di masa yang akan datang, tanpa melihat perbedaan kelompok atau golongan.

\section{Otonomi Perguruan Tinggi}

Pemberian otonomi kepada perguruan tinggi menyangkut beberapa aspek sebagai berikut:

1. Otonomi eksternal, dalam bentuk pemberian status sebagai badan hokum atau sekarang lebih dikenal dengan sebutan BHMN (Badan Hukum Milik Negara). Sebagai unit independen, perguruan tinggi bukan lagi unit pelayanan Ditjen Dikti Departemen Pendidikan Nasional.

2. Otonomi organisasi, perguruan tinggi memiliki kebebasan untuk menetapkan struktur organisasi, termasuk menetapkan struktur program studi dan kegiatan akademik serta merencanakan sumber daya.

3. Otonomi kelembagaan, di mana perguruan tinggi mempunyai kebebasan untuk menetapkan bagaimana fungsi dan konstribusi
${ }^{16}$ Departemen Agama RI, Rekonstruksi Sejarah Pendidikan..., hlm. 118 
Darimus, FUNGSI LEMBAGA-LEMBAGA DALAM PELAKS ANAAN...

mereka dalam mengembangkan, melanggengkan, mentransmisikan, dan menggunakan ilmu pengetahuan. Begitu juga, mereka mempunyai kebebasan untuk memutuskan riset apa yang perlu dilakukan dan bagaimana melakukannya, serta dengan pihak siapa saja mereka ingin bekerja sama dalam melakukan penelitian dan pelatihan penelitian. ${ }^{17}$

\section{Tujuan Otonomi Perguruan Tinggi}

Otonomi perguruan tinggi bertujuan :

1. Untuk mengambil keputusan secara bebas sesuai dengan potensi dan kemajuan iptek;

2. Untuk meningkatkan kualitas berbagai inovasi dalam iptek;

3. Untuk meningkatkan kegiatan sosial sebagai perwujudan salah satu tri dharma perguruan tinggi. ${ }^{18}$

\section{Manfaat Otonomi Perguruan Tinggi}

Otonomi Perguruan Tinggi, banyak manfaat yang didapatkan, yaitu sebagai berikut :

1. Dapat merencanakan, melaksanakan, dan mengontrol sumber daya perguruan tinggi secara efektif;

2. Lebih fleksibel dan dinamis dalam menentukan kebijakan perguruan tinggi tanpa menunggu petunjuk dan persetujuan Dirjen Dikti;

3. Lebih realistis untuk melaksanakan visi dan misinya dan

4. Dalam jangka panjang perguruan tinggi menjadi institusi yang independen dari pemerintah, kekuatan sosial, ekonomi, politik dan sebagainya. ${ }^{19}$

\section{Perguruan Tinggi dan Pembangunan Kualitas SDM}

${ }^{18}$ Ibid., hlm.133

${ }^{19}$ Ibid.

Al-Fikra: Jurnal Ilmiah Keislaman, Vol. 5, No. 2, Juli-Desember 2006

Terjadinya perubahan dan perkembangan dunia yang begitu cepat menuntut keunggulan SDM suatu bangsa yang unggul pula agar mampu bersaing dalam iklim yang sangat kompetitif. Hanya manusia yang unggullah yang dapat survive dalam kehidupan yang penuh kompetisi dan ketidakpastian. Oleh karena itu, pembangunan SDM merupakan kebutuhan mutlak dan perguruan tinggi dalam hal ini mempunyai peran sangat strategis.

Pembangunan SDM pada dasarnya merupakan pembangunan manusia sebagai subjek (buman capital), objek (buman resources), dan menikmat pembangunan. Dimensi pembangunan SDM dapat dilihat dari tiga aspek utama, yaitu (1) kuantitas; (2) kualitas; dan (3) mobilitas penduduk. Kualitas penduduk tercermin antara lain dari tingkat kesejahteraan penduduk, yaitu pendidikan, produktivitas dan akhlak mulia menuju pada pencapaian kesejahteraan sosial yang baik. ${ }^{20}$

Salah satu indicator utama peningkatan peningkatan kualitas SDM terlihat dari meningkatnya tingkat pendidikan, di samping indicator lainnya. Berdasarkan Human Development Report 2003, nilai Human Development Index (HDI) atau Indek Pembangunan Manusia (IPM) Indonesia merosot dari 0,684 menjadi 0,682. Hal ini menyebabkan peringkat Indonesia di antara 175 negara juga merosot dari posisi 110 menjadi 112. Kenyataan ini tentu bukan sesuatu yang menggembirakan sebab ternyata bangsa-bangsa lain begitu serius untuk melakukan pembangunan SDM-nya, terutama sekali melalui pendidikan. Dalam kaitan ini, perguruan tinggi dapat menjadi agent of change yang terdepan, yang dapat merespons semua aspirasi perkembangan keilmuan dan kebutuhan pembangunan yang ada. ${ }^{21}$

Untuk melakukan berbagai perubahan, perguruan tinggi di Indonesia memang mengalami kendala yang boleh dikatakan luar biasa sulitnya. Hal ini terutama disebabkan oleh system yang sudah sedemikian terbangun, belum lagi mentalitas para pemimpin dan seniornya yang cukup feodal dan sulit untuk menerima sebuah perubahan. Ini terjadi karena sekian lama perguruan tinggi dibangun

${ }^{20}$ Departemen Agama RI, op.cit, hlm.141

${ }^{21}$ Hasbullah, Otonomi Pendidikan..., hlm. 141-142 
Darimus, FUNGSI LEMBAGA-LEMBAGA DALAM PELAKS ANAAN... dengan system pemerintahan yang sentralistik, yang segala-galanya harus ditentukan oleh pusat.

Sebagai akibat sentralistik dalam beberapa decade penyelenggaraan perguruan tinggi, dampaknya saja melahirkan sifatsifat seperti ambivalen, afirmatif, aragan, dan sebagainya, tetapi juga kesulitan dalam pengembangan dan peningkatan kualitasnya sehingga sulit bersaing dengan perguruan tinggi-perguruan tinggi yang ada diluar negeri. Dalam konteks penyelenggaraan pendidikan tinggi, dampak yang boleh dikatakan cukup fatal dapat dilihat antara lain sebagai berikut :22

1. Matinya kreativitas dan inovasi, dimana adanya peraturan dan perundang-undangan yang sentralistis menjadikan tidak jalannya kreativitas dan inovasi di lingkungan perguruan tinggi. Sebagai contoh, penambahan program studi baru dan distance learning tidak mudah untuk segera dilaksanakan.

2. Kekakuan dan kekacauan dalam penyelenggaraan proses pembelejaran, penelitian dan pengambdian pada masyarakat. Di Indonesia untuk menyelesaikan S1 harus menempuh sebanyak 144-160 SKS. Berdasarkan referensi dari negara-negara lain (Amerika, Australia, Eropa, dan negara ASEAN lain) untuk mencapai gelar B.A., B.Sc (setara S1 di Indonesia) diperlukan hanya 120 SKS. Di Indonesia perguran tinggi yang menerapkan kurikulum 120 SKS dengan menerapkan pengkajian kurikulum secara cermat, sering mendapat teguran.

Persoalan lain yang masih dihadapi perguruan tinggi, selain otonomi perguruan tinggi, adalah masih terjadinya kesenjangan perhatian pemerintah terhadap penyelenggaraan pendidikan tinggi, terutama menyangkut pembiayaan. Kesenjangan tersebut seperti PTN dan PTS, PTN umum dan PTAIN dan lain-lain. Bagi perguruan tinggi swasta memperoleh cipratan $2 \%$ saja setahun dari anggaran Dikti sudah merupakan sesuatu yang luar biasa besarnya. Begitu juga anggaran pembiayaan perguruan tinggi yang berada di bawah departemen agama, meskipun statusnya negeri, namun pembiayaan masih sangat kurang. Bahkan berdasarkan hasil penelitian, biaya

22 Ibid., hlm. 142
A1-Fikra: Jurnal Ilmiah Keislaman, Vol. 5, No. 2, Juli-Desember 2006

operasional yang diberikan pemerintah terhadap 14 IAIN seIndonesia, tidak lebih besar dibandingkan sebuah perguruan tinggi di Yogyakarta. ${ }^{23}$

Dalam konteks pengembangan SDM, perguruan tinggi merupakan lembaga yang berupaya mencetak SDM tingkat tinggi, yang akan menjadi penggerak dan pemimpin masyarakatnya. Untuk meningkatkan kualitas suatu perguruan tinggi, diperlukan tenagatenaga dosen handal dan bermutu. Sejalan dengan itu, perguruan tinggi juga harus mampu melakukan kiprahnya dalam habitatnya yaitu melaksanakan penelitian, baik yang diperlukan oleh masyarakat sekitar maupun bagi pengembangan ilmu pengetahuan.

Disamping itu diperlukan reformasi tentang penyelenggaraan pendidikan, dalam upaya peningkatan kualitas, diperlukan juga beberapa kondisi, antara lain :24

1. Adanya komitmen politik pada perencanaan pendidikan;

2. Perencanaan pendidikan harus tahu betul apa yang menjadi hak, tugas dan tanggungjawabnya;

3. Harus adanya perbedaan yang tegas antara area politis, teknis dan administrative pada perencanaan pendidikan;

4. Perhatian lebih besar diberikan pada penyebaran kekuasaan untuk membuat keputusan politis dan teknis;

5. Perhatian lebih besar lebih besar diberikan pada pengembangan kebijakan dan prioritas pendidikan yang terarah;

6. Mengurangi politisasi pengetahuan;

7. Harus berusaha leih besar untuk mengetahui opini publik terhadap perkembangan masa depan dan arah pendidikan;

8. Administrator pendidikan harus lebih aktif mendorong perubahan dalam perencanaan pendidikan;

9. Ketika pemerintah tidak menguasai lagi semua asfek pendidikan, harus lebih diupayakan kerjasama yang saling menguntungkan antara pemerintah-swasta-perguruan tinggi yang memegang otoritas pendidikan.

${ }^{23}$ Ibid., hlm. 143

${ }^{24}$ Ibid., hlm. 144 
Darimus, FUNGSI LEMBAGA-LEMBAGA DALAM PELAKS ANAAN...

Beberapa organisasi di negara maju telah menunjukan keberhasilan dengan menggunakan praktek pengelolaan SDM yang efektif melalui cara peningkatan keterampilan dan keahlian SDM organisasi. Beberapa praktek yang telah dikembangkan lembaga konsultan seperti HAY di Eropah (Mitrani, Dalziel and Fitt, 1992) adalah $:^{25}$

1. Mengidentifikasi skill dan kualitas SDM yang serasi dengan tuntutan lingkungan.

2. Memilih SDM yang memilih kinerja tinggi dan potensial.

3. Berusaha memenuhi kebutuhan organisasi dan individu.

4. Menilai kinerja dan keahlian SDM.

5. Memberi kompensasi yang memadai kepada tenaga yang trampil dan memiliki keahlian.

6. Membanguan lingkungan kerja yang baik.

7. Meningkatkan motivasi untuk perbaikan kerja.

Akhirnya, dalam upaya meningkatkan peran dan kualitas perguruan tinggi ke depan, akuntabilitas dan kemandirian perguruan tinggi merupakan suatu keharusan. Oleh karena itu para penyelenggara perguruan tinggi sekarang perlu melakukan intropeksi dan retrospeksi sejauhmana hal tersebut sudah dilakukan. Perguruan tinggi yang memperhatikan akuntabilitas, sudah pasti akan melibatkan partisipasi masyarakat. Dalam hal ini tidak saja dalam bentuk pengelolaan, tetapi program-program yang dikembangkan perguruan tinggi harus menyahuti atau mempunyai relevansi dengan berbagai kebutuhan dan kepentingan masyarakat.

Berkenan dengan kebijakan pelaksanaan dan desentralisasi pendidikan tersebut, ada beberapa hal yang perlu mendapat perhatian, yaitu sebagai berikut:

1. Pelaksanaan desentralisasi pendidikan hendaknya lebih memberikan kebebasan kepada masyarakat untuk memilih pelayanan pendidikan sesuai dengan keinginannya, tidak ada semacam upaya menggiring kearah tertentu kepada masyarakat

25 Soetjipto, Budi W, Paradigma Baru Manajemen Sumber Daya manusia, (Jogjakarta: Penerbit Amara Books, 2002), hlm. 105.
A1-Fikra: Jurnal Ilmiah Keislaman, Vol. 5, No. 2, Juli-Desember 2006 baik secara operasional maupun pola pikirnya (demokrasi pendidikan).

2. Pelaksanaan desentralisasi hendaknya bisa lebih memeratakan pelayan pendidikan dan rasa adil kepada masyarakat. Jangan sampai pelayan pendidikan hanya dapat dinikmati oleh sekelompok masyarakat tertentu dengan mengorbankan kelompok masyarakat yang lainya (pemerataan dan keadilan).

3. Pelaksanaan desentralisasi harus mampu mengakomodasi keragaman potensi dan kondisi social budaya antar daerah. Dengan demikian, antar daerah kabupaten dan kota yang saling berbatasan secara geografis mungkin saja pelayan dan metode pelaksanaan pendidikan berbeda, karena potensi dan social budaya yang berbeda.

4. Pelaksanaan system desentralisasi pendidikan dapat menumbuhkan budaya bersaing dan bersanding antar daerah. Jangan sampai desentralisasi pendidikan justru mematikan motivasi dan kreativitas, sehingga tidak menumbuhkan budaya bersaing dan bersanding di masyarakat.

\section{Kesimpulan}

Banyak harapan dan optimisme bahwa dengan diterapkannya otonomi daerah akan meningkatkan kualitas pendidikan di Indonesia. Namun tidak sedikit juga pesimis, mengingat pelaksanaan otonomi daerah harus melibatkan banyak unsure, terutama sangat tergantung pada aktor pembuat kebijakan di daerah yang terkadang kurang berpihak pada pengemangan pendidikan, sehingga melahirkan sejumlah permasalahan baru. Walaupun dalam pelaksanaan desentralisasi pendidikan ditemui berbagai permasalahan dan terkesan tergesa-gesa, bahkan ada kekhawatiran pihak-pihak tertentu, namun pada dasarnya desentralisasi pendidikan merupakan sebuah keharusan, ia merupakan solusi dari system pendidikan yang berlaku selama ini yang bersifat sentralistik.

Secara konseptual system desentralisasi pendidikan memang lebih luwes dan fleksibel untuk menyesuaikan penyelenggaraan program pendidikan dengan kondisi daerah setempat dibandingkan dengan 
Darimus, FUNGSI LEMBAGA-LEMBAGA DALAM PELAKS ANAAN... system yang sentralistik. Dan ketersediaan sumber daya pendidikan merupakan factor utama dalam penyelenggaraan pendidikan di daerah, di samping juga para pemimpin yang sangat menentukan berhasil, berkembang dan maju tidaknya pendidikan di daerah yang bersangkutan.

Manajemen Berbasis Sekolah (MBS) sebagai perwujudan pelaksanaan desentralisasi pendidikan merupakan strategi pengelolaan penyelenggraan pendidikan di sekolah yang menekankan pada pengerahan dan pendayagunaan sumber internal sekolah dan lingkungannya secara efektif dan efisien sehingga diharapkan menghasilkan output yang lebih berkualitas.

\section{Bibliografi}

Abdullah, Taufik, School and Politic: The Kaum Muda Movement in West Sumatra, (New York: Cornel University, 1971).

Amsyari, Fuad, Masa Depan Umat Islam Indonesia, (Bandung: al-Bayan, 1993)

Arifin, M., Perbandingan Pendidikan Islam, (Jakarta: Rineka Cipta, 2002).

Budi, Soetjipto, Paradigma Baru Manajemen Sumber daya Manusia, (Jogjakarta: Penerbit Amara Books, 2002).

Departemen Agama RI, Rekonstruksi Sejarah Pneidikan Islam di Indonesia, (Jakarta: Direktorat Jenderal Kelembagaan Islam, 2005)

Dep.Pendidikan dan Kebudayaan, Pendidikan di Indonesia dari Jaman ke Jaman, (Jakarta: PN Balai Pustaka, 1985).

Dhofier, Zamakhsari, Tradisi Pesantren, Studi Pandangan Hidup Kyai, (Jakarta: LP3ES, 1986).

Flippo, Edwin B., Manajemen Personalia, edisi keenam, jilid I, Jakarta: Erlangga, 1996).

Halim, Abdul, Akuntansi dan Pengendalian Keuangan Daerah, (Jogyakarta: UPP AMP YKPN, 2002).
Al-Fikra: Jurnal Ilmiah Keislaman, Vol. 5, No. 2, Juli-Desember 2006

, Manajemen Keuangan Daerah, edisi I, Jogyakarta: UPP AMP YKPN, 2001).

Hamka, Kenang-Kenangan Hidup, (Jakarta: Gapura, 1951).

Hasbullah, Otonomi Pendidikan, Kebijakan Otonomi Daerah dan Implikasinya terhadap Penyelenggaraan Pendidika, Jakarta: RajaGrafindo Persada, 2006).

Sejarah Pendidikan Islam di Indonesia, (Jakarta: Raja Grafindo, t.t).

Hendropuspito, Sosiologi Agama, (Jakarta: Kansius, 1988).

Hitami, Munzir, Mengonsep Kembali Pendidikan Islam, (Pekanbaru: Infinite Press, 2004).

Isa, Kamal Muhammad, Manajemen Pendidikan Islam, (Jakarta: Penerbit, Fukahati Aneska, 1994).

Jahrie, A.Fikri, Human Resources Management, (Jakarta: Ensena Dila Offset, 1999).

Langgulung, Hasan, Asas-Asas Pendidikan Islam, (Jakarta: Pustaka alHusna, t.t)

Lembaga Adminsitrasi Negara, Sistem Manajemen Kinerja Otonomi Daerah, Jakarta: Pusat Kajian Kinerja Otonomi Daerah, LAN, 2004)

Maksum, Madrasah, Sejarah dan Perkembangannya, (Jakarta: Logos, Wacana Ilmu, 1999).

Mangkuprawira, Sjafri, Manajemen Sumber Daya Manusia Strategik, (Jakarta: Ghalia Indonesia, 2003).

Prawiranegara, Alamsyah Ratu, Pembinaan Pendidikan Agama, (Jakarta: Depag RI, 1982)

Rais, Amin, Cakrawala Islam, Antara Cita dan Fakta, (Bandung: Mizan, 1989).

Tilaar, H.A. M., Manajemen Pendidikan Nasional, Kajian Pendidikan Masa Depan, (Bandung: Penerbit Rosdakarya, 2001). 
Darimus, FUNGSI LEMBAGA-LEMBAGA DALAM PELAKS ANAAN...

Yunus, Mahmud, Sejarah Pendidikan Islam, Jakarta: Hidakarya Agung, 1979). 